\title{
Hermit beetle's (Osmoderma eremita Scopoli, 1763) occurrence in roadside double row of willows
}

\author{
ELŻBIETA DUSZA, ${ }^{1}$ RENATA GAMRAT ${ }^{2}$
}

West Pomeranian University of Technology, Szczecin, Faculty of Environmental Management and Agriculture, Department of Ecology, Environmental Protection and Management, ul. Słowackiego 17, 71-434 Szczecin, Polska e-mail: elzbieta.dusza@zut.edu.pl

e-mail: renata.gamrat@zut.edu.pl

Keywords Osmoderma eremita, Salix alba, hedge, roadside

Abstract The aim of the research presented in this paper was to assess the state of trees' health in roadside double row of aged white willows regarding the possibility of the protected species of hermit beetle's occurrence. The study was conducted in years 2013 and 2014 on a double row of trees located along the roadside of unpaved local road connecting two farms in the Kuyavian-Pomeranian Voivodeship (town Jarantowiczki, Wąbrzeźno district, municipality of Wąbrzeźno). Detailed study included $500 \mathrm{~m}$ long section of double row topped tree formation of aged white willows Salix alba, on which the presence of hermit beetle Osmoderma eremita was observed. The most serious threat to the hermit beetle is tree-felling in aged tree rows, which are their natural habitat and at the same time ecological corridor that allows connectivity with other populations of this species in the area. Therefore, it is important to preserve in the agricultural landscape as many cavity trees as possible. Especially important within this matter is to conduct local research on small areas, and provide detailed inventories of natural areas for investment.

\section{Występowanie pachnicy dębowej Osmoderma Eremita Scopoli, 1763 w przydrożnym szpalerze wierzbowym}

Słowa kluczowe Osmoderma eremita, Salix alba, szpaler drzew, przydroże

Streszczenie

Celem badań przedstawionych w niniejszym artykule jest ocena stanu zdrowotnego drzew przydrożnego szpaleru wiekowych wierzb białych pod kątem możliwości wystąpienia chronionego chrząszcza - pachnicy dębowej. Badania przeprowadzono w latach 2013-2014 na szpalerze drzew przydrożnych zlokalizowanym wzdłuż nieutwardzonej drogi gminnej łączącej dwa gospodarstwa rolne w województwie kujawsko-pomorskim (miejscowość Jarantowiczki, powiat wąbrzeski, gmina Wąbrzeźno). Badaniami szczegółowymi objęto $500 \mathrm{~m}$ odcinek zadrzewienia szpalerowego zdominowany przez ogłowione, stare wierzby białe Salix alba, na którym obserwowano obecność pachnicy dębowej Osmoderma eremita.

Najpoważniejszym zagrożeniem dla pachnicy dębowej jest wycinka starych alei drzew, które są ich siedliskiem i jednocześnie korytarzem ekologicznym umożliwiającym łączność z pozostałymi populacjami tego gatunku na danym terenie. Dlatego tak ważne jest zachowanie 
w krajobrazie rolniczym starych dziuplastych drzew. Szczególnie istotnym w tym zakresie staje się prowadzenie badań lokalnych, na niewielkich obszarach oraz szczegółowe inwentaryzacje przyrodnicze obszarów przeznaczonych do zainwestowania.

\section{Introduction}

The most common, outstanding area of natural beauty is the one characterized by significant natural values, sensitive to anthropogenic perturbations that can lower its rank. However, not all areas rich in terms of the characteristics of the natural environment are and may in the future be covered by the legal forms of protection. Very often these are small areas (the position of the protected plant) or they have a linear form (piece of roadside plantings). However, it is important to preserve this type of areas, because they are characterized by huge biodiversity, especially valuable in a monotonous agricultural landscape (Liżewska \& Zwierowicz 2009; Gamrat et al. 2011; Bardgett \& van der Putten 2014; Gonthier et al. 2014). Forestation of open areas, as for example fields, serve as refuges for all kinds of living organisms, which found their ecological niche in the anthropogenic landscape. With regard to midfield woodlots having the form of the avenues or tree rows, especially important is their function of ecological corridors, which means areas to facilitate the movement of organisms for long distances (Ranius \& Hedin 2001; Kosmala \& Rosłon-Szeryńska 2012). One of the insects, whose further preservation in rural areas is dependent on the occurrence of rows of trees, is hermit beetle Osmoderma eremita (Oleksa et al. 2013; Barnosky et al. 2011).

Hermit beetle is a brownish-olive large beetle (up to $3 \mathrm{~cm}$ ), belonging to the order of Coleoptera, subfamily of Cetoniidae Oleksa 2010; Zauli et al. 2016). In Poland, it is considered as species of "high risk exposed to extinction," or the species "particularly important." Under the Regulation of the Minister of the Environment (Journal of Laws, 2014) it was covered by strict species protection and as a priority species of the EU it was covered by Habitats Directive 92/43/EEC. This weakly flying insect owes its Polish name (pachnica dębowa) to alluring females secreted pheromones, which reminds a scent of plum and apricot (Larsson et al. 2003).

In Poland, the hermit beetle occurs throughout the country, but especially in large numbers in Warmian-Masurian Voivodeship, Lubusz Voivodeship, Greater Poland, Opole Voivodeship, Lower Silesian Voivodeship and Świętokrzyskie Voivodeship (Kadej et al. 2007; Bernacki \& Karg 2008). As habitat it selects the aged, cavity grouped species of trees, mainly oak, beech - species of hardwood, with extensive touchwood formations. Currently, such tree formations are rare, and therefore it was observed that it colonizes replacement habitat, such as aged, rotten species of willows and lindens - species with soft wood, formed as roadside avenues (Oleksa et al. 2007).

The aim of the research was to assess the state of trees' health in roadside double row of aged white willows regarding the possibility of the protected species of hermit beetle's occurrence.

\section{Material and Methods}

In years 2013 and 2014 there were carried out the dendrological and faunological studies of the roadside double row located along the unpaved local road connecting the two farms in the Kuyavian-Pomeranian Voivodeship (town Jarantowiczki, Wąbrzeźno district, municipality of Wąbrzeźno) - Figure 1. Detailed study included $500 \mathrm{~m}$ long section of double row topped tree formation of aged white willows Salix alba, on which the presence of hermit beetle Osmoderma eremita was observed. 


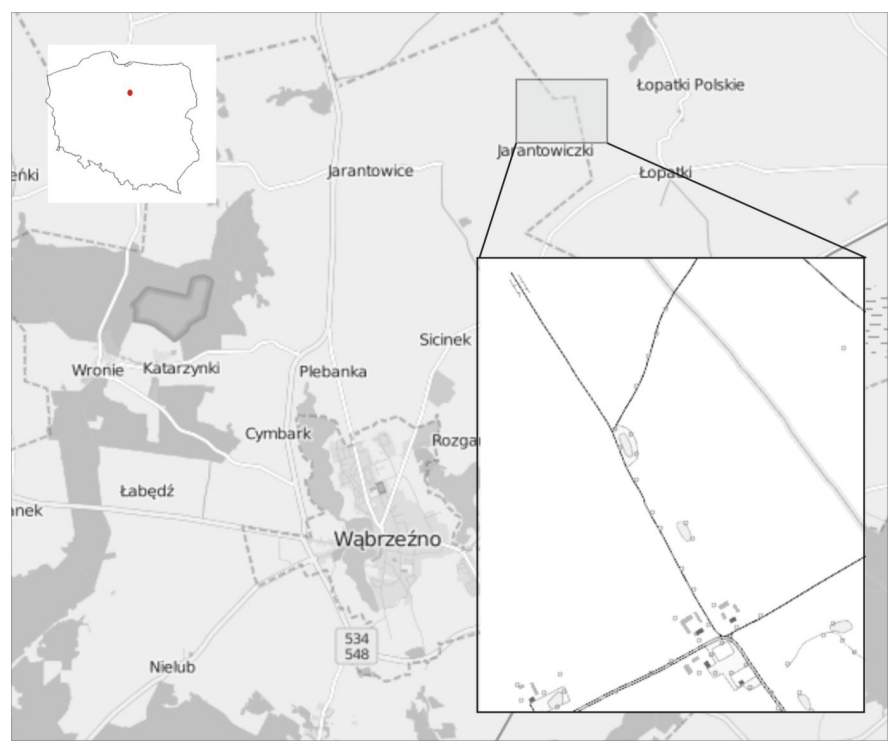

Figure 1. Location of the research area (own work)

The presence of a protected beetle was found by observation: of adult specimens or feces of larvae in the months of July-August during sunny weather with the air temperature above $24^{\circ} \mathrm{C}$ (Oleksa 2010; Larsson \& Svensson 2011). There has also been analyzed the composition of tree species and conducted basic dendrometric measurements: trunk circumference, height of the specimen and the crown diameter. Additionally, the state of the trees' health was stated (modification Liżewska \& Zwierowicz 2009 - table 1). Tree sizes were compared to the size of trees of monumental dimensions, adopting the criterion of $3 \mathrm{~m}$ trunk circumference at a height of $1.30 \mathrm{~m}$ (Pietrzak-Zawadka 2015).

Table 1. The condition of trees in the study area (own work)

\begin{tabular}{|l|l|}
\hline $\begin{array}{l}\text { The condition of trees } \\
\text { in the study area }\end{array}$ & Description of the health status of trees \\
\hline very good & very good health condition, without breakdown, correct sort \\
\hline good & $\begin{array}{l}\text { good health condition, few surface and deep losses, formed crown, small } \\
\text { deadwood, single hidey-holes }\end{array}$ \\
\hline satisfactory & $\begin{array}{l}\text { good health condition, numerous surface and deep losses, branches and twigs } \\
\text { broken off, hidey-holes about significant sizes, cracks of the trunk from } \\
\text { the base until the crown }\end{array}$ \\
\hline weak & $\begin{array}{l}\text { bad state of health (partly dying), numerous surface and deep losses, branches } \\
\text { and twigs broken off, cracks of the trunk from the base until the crown, shaken } \\
\text { statics of the tree }\end{array}$ \\
\hline bad & very bad state of health (dead, isn't promising for surviving) \\
\hline
\end{tabular}




\section{Results and Discussion}

While carrying out various investments, for example, roads modernization, preservation of valuable areas of nature takes on a new meaning. Midfield woodlots are not just a diversity of monotonous agricultural landscape, biodiversity refuges, but also measurable value to people (Bulak et al. 2010; Kędziora \& Karg 2010). The preservation of the principles of sustainable development makes the investment planning to focus on assessing the ecological value of the area and to carry out proper investment process aimed at respecting the rights of nature (Staniak 2009; Smith et al. 2015).

Polish landscapes preserved its natural values in an incomparably greater extent than the neighboring Western countries. However, also here changes in the characteristic features of the landscape in different regions can be recognized. In the area of Eastern and Central Poland double rows of willows, planted next to the ditches, midfield roads in the form of wind protecting lanes were common until World War II. Today, however, they are less and less common (Witusińska et al. 2009; Kuszewska \& Fenyk 2010).

In the researched roadside area there were three tree species (28 specimens): Salix alba, Pirus communis and Alnus glutinosa (Figure 2). Among the identified species of trees 20 specimens of Salix alba were topped. Other specimens of willows and other species have unthinned branches.

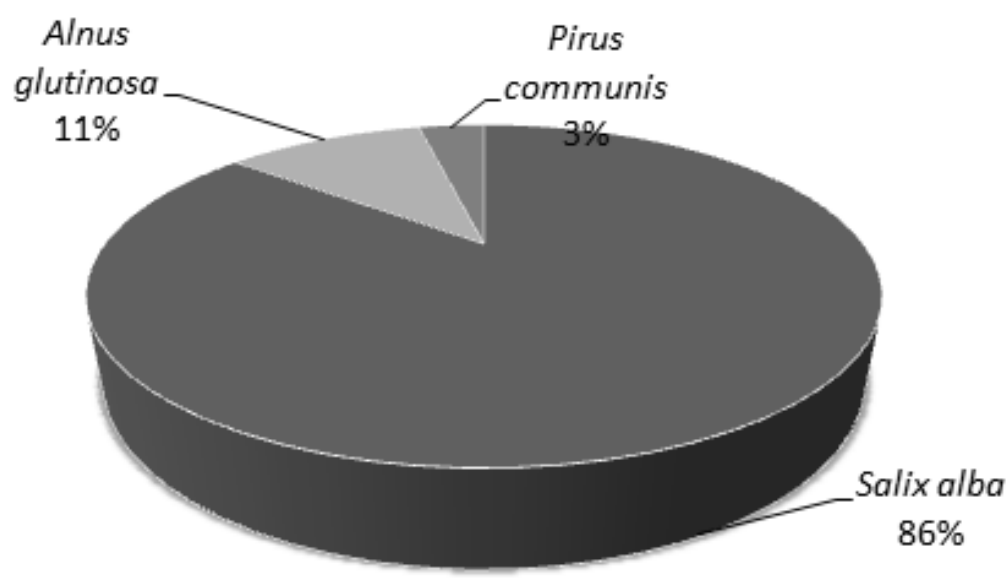

Figure 2. Species composition of trees of the studied area (own work)

Analysis of the state of trees' health showed that $64 \%$ of trees are in good health condition, although it was found that they have numerous defects and broken branches, but it can be considered as characteristic for the white willow species, especially those specimens that were subject of successive topping treatments. These trees are in good health and it is not expected any deterioration of their condition in the near future. Five specimens of trees were classified into the group of sufficient state of preservation. They were topped, had broken branches and boughs, scars from cuts, surface defects, small cavities, were partially rotten (from the top).

Also, five specimens of trees were classified to the group of poor preservation status. Trees were characterized by lost of their branches and boughs, had numerous scars from cuts, defects 
on the surface and small holes, cavities and rotting wood formations inside the trunk, and sometimes they had partially rotten or hollow trunk. Despite such unfavorable changes all the trees have survived alive and during the observation no trees completely dead were found.

Topping treatments performed by a too vast cuts or in the wrong year period cause disturbances in the biological balance of plants, which leads to the rapid invasion of all fungal diseases. Drastic reduction of branches, deprives from the tree such number of leaves that it goes into hunger mode and becomes prone to extensive wounds, and ultimately it may lead to its death (2008 Suchocka; Gamrat et al. 2011). However, the species with soft wood, such as white willow or linden may be subjected to systematic topping from the earliest stages of development. As a result trunk grows, creating a unique shape called a willow head. In such modified form, they are a characteristic part of the natural landscape in many regions of Poland (Dolatowski 2000).

On trees of roadside avenue that was the base of the study, there was observed the occurrence of species covered by strict protection - hermit beetle Osmoderma eremita (Journal of Laws, 2014), in the form of adult specimens and feces of larvae (Photo 1). It was present on eight of topped aged specimens of white willows Salix alba. The adult specimens (imago) has been recognized on the trunks of researched trees, and in several internal touchwood formations feces of hermit beetle and two dead adults specimens were identified (Table 2).
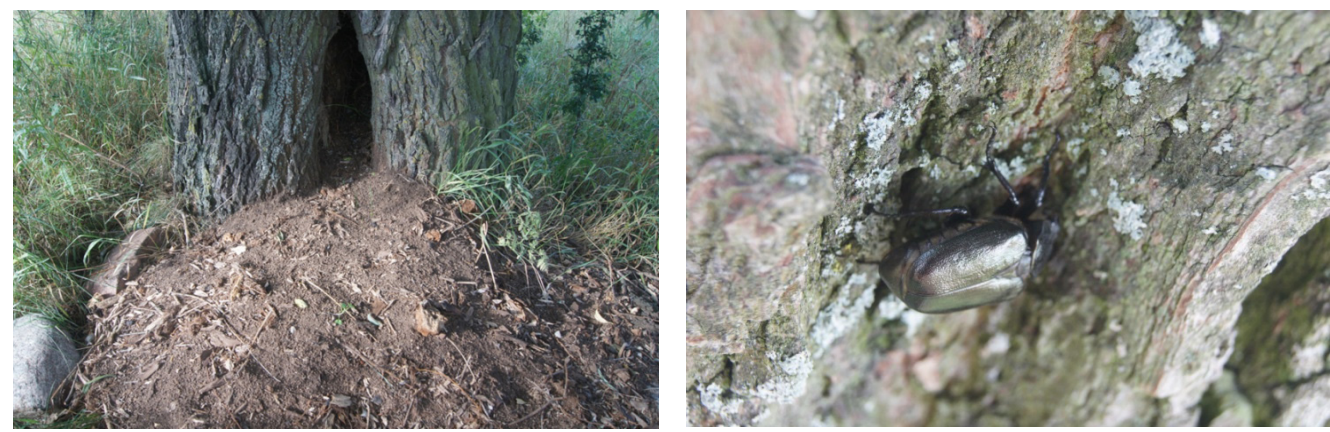

Photography 1. The adult specimen of the beetle and the position of Osmoderma eremita (photo E. Dusza)

Habitat of the hermit beetle is associated with anthropogenic cultural landscapes with a sufficiently high density of trees, which often are roadside plantings. This insect during almost whole of his life resides inside cavities of aged trees. Therefore, detection of this species in the area is very difficult, because only $2 \%$ of the duration of the entire life cycle of these insects can be found outside cavities - time an adult specimen life. This species prefers primarily large cavity trees growing in a sunny spots. Shaded locations are inhabited by hermit beetle much less often, mainly due to unfavorable thermal conditions (Lindhe et al. 2005). Species normally inhabit aged trees having more than 100 years. They are usually cavity trees, but still alive and standing (Zauli et al. 2016). Protection of this species provides simultaneous protection of biodiversity associated with cavity trees, because it is scientifically proved that the trees inhabited by the hermit beetle are characterized by a high diversity of life represented by the numerous groups of organisms, plants, fungi, invertebrates and vertebrates (Barnosky et al. 2011). 
Table 2. Biometric measurements of trees along with the assessment of medical condition and appearing of Osmoderma eremita

\begin{tabular}{|c|c|c|c|c|c|c|}
\hline Lp. & $\begin{array}{c}\text { Name } \\
\text { of the species }\end{array}$ & $\begin{array}{l}\text { circumference } \\
\text { of the trunk } \\
{[\mathrm{cm}]}\end{array}$ & $\begin{array}{c}\text { Diameter } \\
\text { of the crown } \\
{[\mathrm{m}]}\end{array}$ & Height $[\mathrm{m}]$ & State of health & $\begin{array}{c}\text { Appearing } \\
\text { of Osmoderma } \\
\text { eremita }\end{array}$ \\
\hline 1 & Salix alba & $328^{*}$ & 6 & 4 & good & \\
\hline 2 & Salix alba & $353^{*}$ & 10 & 6 & good & \\
\hline 3 & Salix alba & $408^{*}$ & 8 & 6 & good & \\
\hline 4 & Salix alba & $413^{*}$ & 10 & 7 & satisfactory & \\
\hline 5 & Salix alba & $409 *$ & 8 & 6 & satisfactory & \\
\hline 6 & Salix alba & $323^{*}$ & 8 & 6 & good & imago \\
\hline 7 & Salix alba & $412 *$ & 8 & 6 & satisfactory & \\
\hline 8 & Salix alba & 205 & 8 & 7 & good & imago \\
\hline 9 & Salix alba & $438^{*}$ & 9 & 8 & good & \\
\hline 10 & Salix alba & $407^{*}$ & 8 & 6 & good & \\
\hline 11 & Salix alba & $404 *$ & 9 & 7 & good & \\
\hline 12 & $\begin{array}{l}\text { Pyrus } \\
\text { communis }\end{array}$ & $16 ; 18 ; 21$ & 2 & 3 & good & \\
\hline 13 & Salix alba & $307^{*}$ & 10 & 7 & good & \\
\hline 14 & Salix alba & $336^{*}$ & 6 & 4 & good & \\
\hline 15 & Salix alba & 282 & 18 & 10 & good & \\
\hline 16 & Salix alba & $357^{*}$ & 20 & 10 & good & \\
\hline 17 & Salix alba & $354 *$ & 8 & 6 & satisfactory & \\
\hline 18 & \begin{tabular}{|l} 
Alnus \\
glutinosa
\end{tabular} & 82 & 7 & 6 & good & \\
\hline 19 & \begin{tabular}{|l|}
$\begin{array}{l}\text { Alnus } \\
\text { glutinosa }\end{array}$ \\
\end{tabular} & 57 & 6 & 6 & good & \\
\hline 20 & \begin{tabular}{|l} 
Alnus \\
glutinosa
\end{tabular} & 37 & 7 & 6 & good & \\
\hline 21 & Salix alba & $376^{*}$ & 20 & 10 & good & imago, koprolity \\
\hline 22 & Salix alba & 265 & 15 & 9 & good & imago, koprolity \\
\hline 23 & Salix alba & $350^{*}$ & 6 & 5 & weak & \\
\hline 24 & Salix alba & $353^{*}$ & 13 & 8 & weak & \\
\hline 25 & Salix alba & 248 & 14 & 9 & weak & koprolity \\
\hline 26 & Salix alba & $318^{*}$ & 14 & 9 & satisfactory & $\begin{array}{l}\text { imago, koprolity, } \\
\text { martwe imago }\end{array}$ \\
\hline 27 & Salix alba & $452 *$ & 10 & 8 & weak & imago, koprolity \\
\hline 28 & Salix alba & 269 & 10 & 8 & weak & imago, koprolity \\
\hline
\end{tabular}

Explanations: $*$ - trees having sizes of monumental trees.

According to the monitoring data (Oleksa 2012) it can be stated that the hermit beetle is relatively widely represented in the Kuyavian-Pomeranian Voivodeship, and the state of species preservation can be considered as appropriate. It is connected with the occurrence in Pomerania of characteristics cultural landscapes, which include historically shaped green roadside rows of trees along the roads and avenues, and quite frequently occuring post-manorial and post-palace parks. 
Hermit beetle researches in Lower Silesia pointed its 745 habitats, 88\% of which are single locations of inhabited trees. Other habitats include groups of trees formed as an avenue or woodlots. Most of the hermit beetles' habitats in the area of study (59\%) are located in forest areas. Out of the 443 forest habitats $78 \%$ are located in commercial forests. In the avenues and parks there is respectively $24 \%$ and $11.5 \%$ of the habitats. The rest are biotopes such as: linear plantings at riversides, cemeteries or lone standing trees (Kadej et al. 2014).

Of the assessed 28 specimens forming roadside plantings or tree rows along the unpaved roads, 19 can be considered as a potential natural monuments. Trunks circumference was ranged from 3.1 to $4.5 \mathrm{~m}$, with an average value within listed specimens of $3.8 \mathrm{~m}$. The height of these trees depended on the topping. It ranges from 6 to $20 \mathrm{~m}$. Other tree from the white willow species occurring in the area, that are forming the dominant species in this midfield avenue, despite the smaller trunk circumference, also deserve the absolute preservation.

The researched roadside area, on a section of $500 \mathrm{~m}$, is a valuable natural object, since the distance between the individual specimens of trees is small and ranges from 6 to $8.5 \mathrm{~m}$ in several clusters. Also the distance between the clusters of individual trees is not more than 20 $\mathrm{m}$ (Figure 3). Thanks to that, such conditions seem to be an ideal place of hermit beetles' living, because it does not move for long distances and rather is devoted to one area. The small distance between the individual specimens of trees, their sizes and species (significant touchwood formations) creates an ideal habitat for the development of this rare beetle. This is particularly important considering the fact that the crucial for protection of hermit beetles is the problem of increasing isolation of its habitats.

Trees-felling during roads modernization, enhances isolation and reduces the chances of survival of the hermit beetles, especially since this insect has slight opportunity to move - up to $300 \mathrm{~m}$ (Svensson et al. 2004; Chiari 2012). Two-year monitoring study carried out by Chiari et al. (2013), regarding the spreading of hermit beetles in the forests of cork oak in central Italy showed that $39 \%$ of the population of this species dispersed only to $250 \mathrm{~m}$. The longest migration observed was $1504 \mathrm{~m}$. On a single tree was found only a few specimens in imago form. Most adults leave their tree. In order to preserve the population of that species, it is desirable that the respective tree are grouped in the field of maximum several hundred meters. Studies of Dubois et al. (2010) on the size of the hermit beetles' spreading carried out for more than 30 specimens in different regions of France, indicated on several parameters (gender, number of specimens) affecting the degree of migration. There was stated a higher ability to fly within females than within males, though they were in worse condition. A single maximum flight of the specimen was 1,6-fold faster than a group (respectively $1.5 \mathrm{~m}$ and $2.4 \mathrm{~m}$ ). Flight speed within females depended on the health condition. Investigated factors indicated that males and females have different policies and thus the different possibility of spreading.

As an organism with the small capacity of dispersion hermit beetle is not able to colonize distant and heavily isolated habitats. Therefore, using the knowledge of its migration, it is worth to plan (by planting trees) and keep (by protecting) any linear tree plantings (e.g. avenues, rows) that may be useful to connect local small populations. Outside observers or people not aware of relationships of biological processes rarely know that tree-felling in any place of aged avenues or rows and cavity (often monumental) trees can cause loss of communication and consequently isolate specimens from each animal subpopulations (Ranius \& Hedin 2001). 


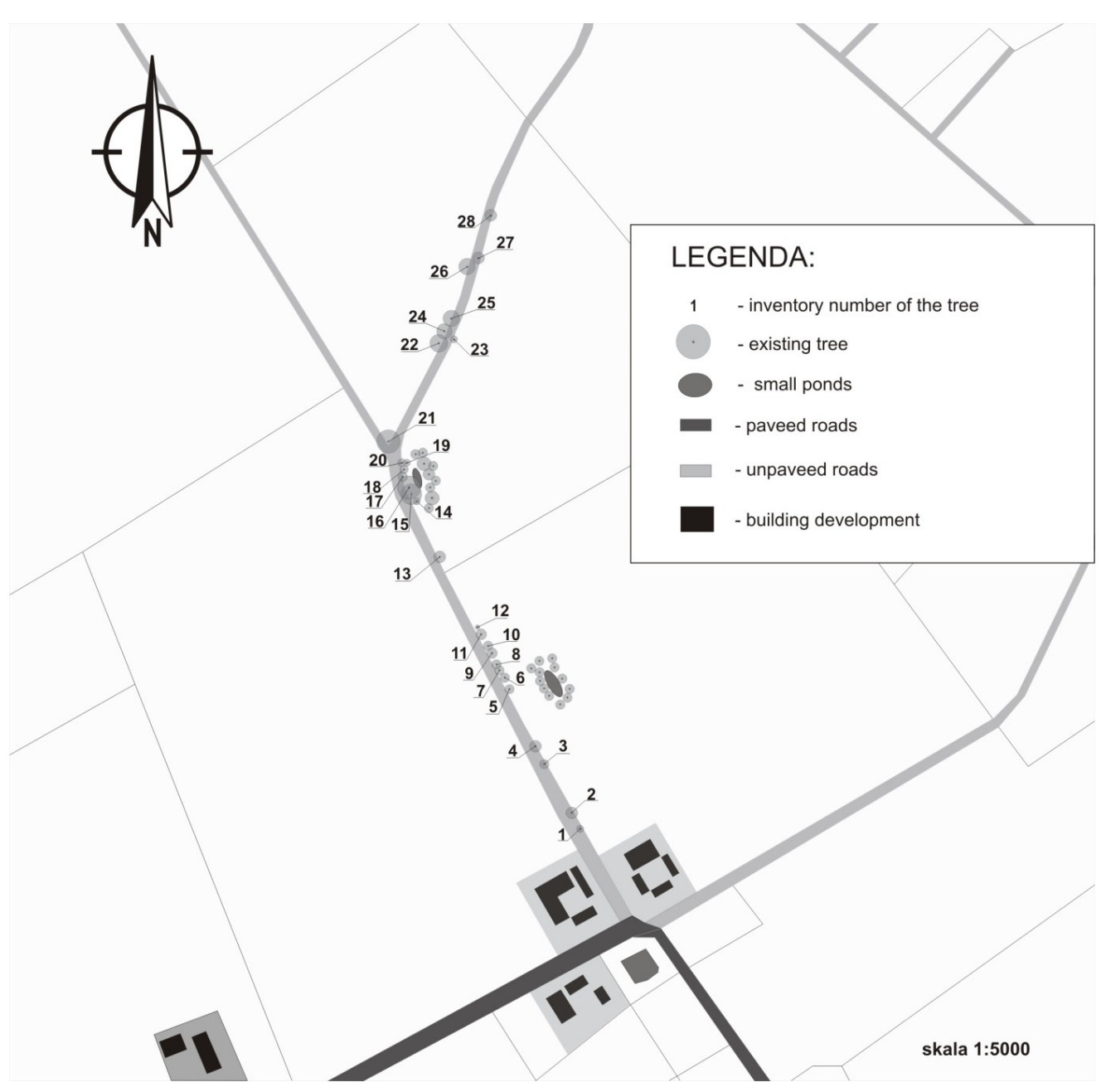

Figure 3. The location of individual trees of the study area

In order to preserve the population of hermit beetle Osmoderma eremita, management actions should be aimed at increasing the density of cavity trees and volume of tree cavities by fostering the natural aging of trees and the creation of artificial habitats in live trees (Chiari et al. 2014). Giangregorio et al. (2015) believed that in order to keep hermit beetle Osmoderma eremita it should be allowed to it. Ten years of experience in the forest dominated by aged beech next to Sant 'Antonio created habitats for this species. During the tree-felling (specimens $>30 \mathrm{~m}$ in height and circumference of $>4 \mathrm{~m}$ ) and during forestation, some of the older specimens of common beech were topped. 
This led to the creation at the trunks top of vast callus surface (made of callus tissue) accelerating the decay process - providing the optimal environment for hermit beetle. Rocca et al. (2014) showed that the density and small diameter of breast height of trees in the forests have a negative impact on species diversity. In order to increase the presence of saproxylic organisms in extensively developed areas it should be used regular cuttings to provide cutting stumps and secure the continuity of the dead wood. Logging combined with controlled burning o wood particles with downtimes, increases the number of threatened species (Hilszczański 2016).

Monumental size trees, even after their physiological death deserves preservation. They can be used in numerous purposes: educational, historical, historic, commemorative, patriotic. It is a valuable didactic object (Pietrzak 2011).

"there are many examples to show that any activity or treatments aimed to promote biodiversity of saproxylic species in developed forests require, «a multi-scale approach», e.g. local treatments should be performed in a much greater extent than it is now" (Sverdrup-Thygeson et al. 2014).

\section{Conclusion}

The most serious threat to the hermit beetles is a tree-felling of aged rows of trees which are their natural habitat and at the same time ecological corridor that allows connectivity with other populations of this species in the area. Therefore, it is important to preserve the agricultural landscape of aged cavity trees. Especially important, in this regard, it is to conduct local research on small areas, and to provide detailed inventories of natural areas for investment. The results of field studies should determine the trends and opportunities for investment processes while maintaining landscape features that are unique. Nowadays, investors are accommodating environment-friendly solutions, but they must be supported by field studies. Valuable natural areas, which undoubtedly the discussed double row of white willows is, should also get legal protection as monuments or another natural monument (group - in the form of a row). Such number of powerful and aged trees which are the habitats of protected species of beetle is extremely important both for learning, and certainly raises the tourist values of the area.

\section{References}

Bardgett R.D., van der Putten W.H. 2014. Below ground biodiversity and ecosystem functioning. Nature, 515: 505-511.

Barnosky A., Matzke N., Tomiya S., Wogan G., Swartz B., Quental T., Marshall C., McGuire J., Lindsey E., Maguire K., Mersey B., Ferrer E. 2011. Has the earth's sixth mass extinction already arrived? Nature, 471 (7336): 51-57.

Bernacki Z., Karg J. 2008. Zadrzewienia śródpolne jako bariery antyerozyjne i biogeochemiczne. Wydawnictwo Studia i Raporty IUNG - PIB 10, pp. 59-67.

Bulak J., Nowakowski S., Woch W. 2010. Zadrzewienia śródpolne - ważny element tradycyjnego rolnictwa na Żuławach Wiślanych. Wydawca Zarząd Parku Krajobrazowego „Mierzeja Wiślana”, p. 20.

Chiari S. 2012. Ecology of the hermit beetle (Osmoderma eremita) in Mediterranean woodlands. Doctoral school in biology, section: Biodiversity and ecosystem analysis XXIV Cycle Roma TRE Universitar Degli Studi, p. 115. 
Chiari S., Carpaneto G.M., Zauli A., Zirpoli G.M., Audisioand P.T. 2013. Dispersal patterns of a saproxylic beetle, Osmoderma eremita, in Mediterranean woodlands. Insect Conservation and Diversity, 6: 309-318.

Chiari S., Zauli A., Audisio P., Carpanet, G.M. 2014. Interactions between larvae of the threatened saproxylic beetle Osmoderma eremita and other flower chafers in Mediterranean woodlands: implications for conservation. Insect Conservation and Diversity, 7: 462-469.

Dolatowski J. 2000. Ogławiane wierzby. Rocznik Dendrologiczny, 48, 191-195.

Dubois G.F., Gouar P.J., Delettre Y.R., Brustel H., Vernon P. 2010. Sex-biased and body condition dependent dispersal capacity in the endangered saproxylic beetle Osmoderma eremite (Coleoptera: Cetoniidae). Journal of Insect Conservation, 14: 679-687.

DzU. 2014. Rozporządzenie Ministra Środowiska z 6.10.2014 r. w sprawie ochrony gatunkowej zwierząt (DzU. 2014, poz. 1348).

Gamrat R., Młynkowiak E., Podlasiński M. 2011. Aktualny stan alej przydrożnych proponowanych do ochrony w dwóch sąsiadujących gminach Dobrzany i Suchań w województwie zachodniopomorskim. Ekologia i Technika, 19, 3A: 209-214.

Giangregorio P., Audisio P., Carpaneto G. M., Marcantonio G., Maurizi E., Mosconi F., Campanaro A. 2015. Updated distribution of Osmoderma eremita in Abruzzo (Italy) and agro-pastoral practices affecting its conservation (Coleoptera: Scarabaeidae). Fragmenta Entomologia, 47 (2): 139-146.

Gonthier D.J., Ennis K.K., Farinas S., Hsieh H.-Y, Iverson A.L., Batáry P., Rudolphi J., Tscharntke T., Cardinale B.J., Perfecto I. 2014. Biodiversity conservation in agriculture requires a multiscale approach. Proceedings of the Royal Society B: Biological Sciences, 281: 1-8.

Hilszczański J. 2016. Użytkowanie lasu a bioróżnorodność i rola ksylofagów. Wydawnictwo ILB „Puszcza Białowieska - mity, fakty i przyszłość”, Warszawa p. 26.

Kadej M., Ruta R., Malkiewicz A., Smolis A., Stelmaszczyk R., Tarnawski D., Żuk K., Kania J., Suchan T. 2007. Nowe dane o występowaniu pachnicy dębowej Osmoderma eremita (Scopoli, 1763) (Coleoptera, Scarabaeidae) na Dolnym Śląsku. Przyroda Sudetów Zachodnich, 10: 135-150.

Kadej M., Zając K., Tarnawski D., Malkiewicz A., Gil R., Tyszecka K., Smolis A., Myśków E., Bobrowicz G., Sarnowski J., Zawisza M., Józefczuk J., Gottfried T., Zając T. 2014. Pachnica dębowa Osmoderma eremita (Scopoli, 1763) (Coleoptera, Scarabaeidae) w Polsce południowo-zachodniej. Przyroda Sudetów Zachodnich, 17: 89-120.

Kędziora A., Karg J. 2010. Zagrożenia i ochrona różnorodności biologicznej. Nauka, 4: 107-114.

Kosmala M., Rosłon-Szeryńska E. 2012. Wyciąć czy zostawić? In: Aleje - Skarbnice Przyrody. Praktyczny Podręcznik Ochrony Drzew i Ich Mieszkańców. P. Tyszko-Chmielowiec (ed.), Wydawnictwo Fundacja EkoRozwoju, Wrocław, pp. 131-136.

Kuszewska K., Fenyk M.A. 2010. Różnorodność biologiczna w krajobrazie rolniczym. Acta Sci. Pol., Administratio Locorum, 9 (1): 57-68.

Larsson M.C., Hedin J., Svensson G.P., Tolasch T., Francke W. 2003. Characteristic odor of Osmoderma eremita identified as a male- released pheromone. Journal of Chemical Ecology, 29: 575-587.

Larsson M.C., Svensson G.P. 2011. Monitoring spatiotemporal variation in abundance and dispersal by a pheromone-kairomone system in the threatened saproxylic beatles Osmoderma eremita and Elater ferrugineus. Journal Insect Conservation, 15: 891-902.

Lindhe A., Lindelöw Å., Åsenblad N. 2005. Saproxylic beetles in standing dead wood density in relation to substrate sun-exposure and diameter. Biodiversity and Conservation, 14 (12): 3033-3053.

Liżewska I., Zwierowicz M. 2009. Aleje przydrożne - dziedzictwo historyczne, stan zachowania, ochrona. In: Aleje przydrożne. Historia, znacznie, zagrożenie, ochrona. K. Worobiec, I. Liżewska (eds.), Wydawnictwo Borussia, Kadzidłowo-Olsztyn, pp. 95-109. 
Nowak M., Kijowski A., Stachura-Skierczyńska K., Antkowiak M. 2015. Inwentaryzacja zadrzewień -klasyczne metody terenowe a nowoczesne technologie teledetekcyjne. Problemy Ekologii Krajobrazu, 39: 71-78.

Oleksa A. 2010. Pachnica dębowa Osmoderma eremita (Scopoli, 1763). In: M. Makomaska-Juchiewicz (ed.), Monitoring gatunków zwierząt. Przewodnik metodyczny. Część pierwsza. Wydawnictwo Biblioteka Monitoringu Środowiska, Warszawa, pp. 90-111.

Oleksa A., Chybicki I.J, Gawroński R., Svensson G.P., Burczyk J. 2013. Isolation by distance in saproxylic beetles may increase with niche specialization. Journal of Insect Conservation, 17, 2: 219-233.

Oleksa A., Ulrich W., Gawroński R. 2007. Host tree preferences of hermit beetles (Osmoderma eremita Scop., Coleoptera: Scarabaeidae) in a network of rural avenues in Poland. Polish Journal of Ecology, 55: 315-323.

Pietrzak J. 2011. Możliwości wykorzystania obiektów ochrony pomnikowej w edukacji przyrodniczej. Wydawnictwo Studia i Materiały CEPL w Rogowie 13, pp. 52-59.

Pietrzak-Zawadka J. 2015. Kryteria wymiarowe uznawania drzew za pomniki przyrody w Polsce. Sylwan, 159 (3): 227-235.

Ranius T., Hedin J. 2001. The dispersal rate of a beetle, Osmoderma eremita, living in tree hollows. Oecologia, 126: 363-370.

Rocca F.D., Stefanelli S., Pasquaretta C., Campanaro A., Bogliani G. 2014. Effectof dead wood management on saproxylic betele richness in the Floyd Plain forests of northern Italy: some measures for dead wood sustainable use. Journal of Insect Conservation, 18 (1): 121-136.

Staniak M. 2009. Równoważony rozwój obszarów wiejskich w aspekcie środowiskowym. Woda-Środowisko-Obszary Wiejskie, 9, 3 (27): 187-194.

Suchocka M. 2008. Zdolności regeneracyjne drzew i ich odporność na uszkodzenia w środowisku miejskim. Człowiek i Środowisko, 32 (1-2): 5-18.

Svensson G.P., Larsson M.C., Hedin J. 2004. Attraction of the larval predator Elater ferrugineus to the sex pheromone of its prey, Osmoderma eremita, and its implication for conservation biology. Journal of Chemical Ecology, 30: 353-363.

Sverdrup-Thygeson A., Gustafsson L., Kouki J. 2014. Spatial and temporal scales relevant for conservation of dead-wood associated species: current status and perspectives. Biodiversity and Conservation, 23 (3): 513-535.

Witusińska B., Olszewski A., Michalska-Hejduk D. 2009. Przydrożne wierzby jako element krajobrazu kulturowego oraz siedlisko roślin i zwierząt. In: Rola Kampinoskiego Parku Narodowego w zachowaniu różnorodności biologicznej i krajobrazowej dawnych obszarów wiejskich, D. Michalska-Hejduk, A. Bomanowska (ed.), Wydawnictwo Kampinoski Park Narodowy, Łódź-Izabelin, pp. 123-131.

Zauli A., Maurizi E., Carpaneto G.M., Chiari S., Svensson G.P., Giulio A.D. 2016. Antennal fine morphology of the threatened beetle Osmoderma eremita (Coleoptera: Scarabaeidae), revealed by scanning electron microscopy. Microscopy Research and Technique, 79 (3): 178-191.

Cite as: Dusza E., Gamrat R. 2016. Hermit beetle's (Osmoderma eremita Scopoli, 1763), occurrence in roadside double row of willows. Acta Biologica, 23: 35-45. DOI: 10.18276/ab.2016.23-03. 